\title{
MUNICIPAL BONUSES AND TAX EXEMPTIONS TO ENTICE PRIVATE DEVELOPMENTS
}

\author{
F. A. LAUX*
}

The author examines the history and case law of municipal councils granting bonuses and tax exemptions to private businesses in Alberta. He then considers the effect of the recent repeal of s. 443 of the Municipal Government Act. The author concludes that the rule prohibiting such aid to entice private businesses to establish, continue, or expand enterprises in the community remains alive and well in Alberta.

\section{SETTING THE SCENE}

Two high-profile events in Alberta municipal politics in 1986 created substantial public controversy, together with litigation, and gave rise to a question that remains very much in the forefront of the minds of business persons, municipal politicians and their respective legal advisors in these times of economic slump: What are the legal limits on the authority of a municipal council to grant aid and assistance to a private business enterprise to induce such enterprise to establish itself, to continue operations or to expand its operations in the community? A third event, which has achieved virtually no public notoriety, likely will add fuel to the fire of controversy and almost certainly serve to confuse and confound those seeking a simple and straight-forward answer to the question posed.

In 1984 the Calgary Stampeder Football Club Ltd., a community based non-profit corporation, lost nearly $\$ 800,000$ in the course of its operations. In 1985 the numbers in red ink nearly doubled. To head off the unthinkable - that the City of Calgary be left with only two professional sports franchises, its beloved Flames of hockey fame and its equally beloved, but considerably less patronized baseball team, the Cannons the Club directors resolved to offer to sell the football franchise to a group of private investors. The private group was prepared to take up the offer but conditional upon receiving some financial assistance from both the City of Calgary and the Provincial Government.

The financial assistance from the City was initially to be in the form of a $\$ 6 \mathrm{M}$ loan but, after considerable negotiation and discussion, this proposal was changed to a scheme whereby the City was to make annual grants for several years of about $\$ 500,000$ each to the McMahon Stadium Society, a community based non-profit organization that operated McMahon Stadium, the home field of the Stampeders. The intent appears to have been that these grants would permit the Society to reduce the annual rental charge for the Stadium to the football Club, which in turn would enhance the profit and loss picture of the Club in ensuing years and thereby serve as a catalyst to close the take-over deal between the Club and the group of private investors. ${ }^{1}$

A resolution encompassing the scheme was voted on by Calgary City Council on January 20,1986 but was defeated by a one vote margin. The defeat of the resolution was due in part, no doubt, to the fear that such a

* Faculty of Law University of Alberta.

1. See the affidavit of the Applicant and attached exhibits in the Courthouse file in the case of Bell v. City of Calgary, unreported, 1986, J.D. of Calgary, Action No. 8601-07347 (Alta. Q.B.). 
resolution was contrary to the provisions of s. $443^{2}$ of the Municipal Government Act and could result in disqualification from holding office of those council members voting for the resolution. The concern voiced by some of the naysayers was that, while the grant of money was being laundered through the non-profit stadium Society and while non-profit organizations were perhaps not caught by s. 443 , it would in substance amount to a grant to a private business enterprise, the group of investors who would be taking over the Club if the resolution passed. Hence, it was said that the resolution was likely in contravention of s. 443.

The defeat of the resolution resulted in the Club's executive returning to the drawing boards and subsequently deciding to continue operating the team provided that a rescue plan, containing as one principal element a campaign to quickly sell twenty-five thousand season tickets, met with success. The citizens of Calgary rallied behind their team with the consequence that the ticket sale drive was complete by mid-February.

A second key component in the rescue effort was that the City provide a grant for the ' 86 and ' 87 seasons to the Stadium Society, which in turn would provide a rent abatement to the Club. However, s. 443 was again a matter of concern even though, unlike the defeated resolution of January 20 , the new proposal could not be said to benefit a private commercial entity since the ultimate beneficiary of the bounty would be the community owned non-profit organization, the Calgary Stampeder Football Club Ltd.

Apparently in an attempt to allay the concerns of those council members who were not prepared to run the risk of being unceremoniously removed from office by voting in favour of the second component of the rescue effort, a letter dated February 13, 1986 was obtained from the Minister of Municipal Affairs. In that letter the Minister advised the Council that he was prepared to recommend to Cabinet that a regulation be promulgated under s. 10(1) of the Municipal Government Act which would render s. 443 inoperative in respect of a grant made by a council to a non-profit organization and, further, that $\mathbf{s .} \mathbf{4 4 3}$ be amended at the next sittings of the

2. R.S.A. 1980 , c. M-26.

443(1) No council has power

(a) to grant a bonus or other aid to any person, for the construction, establishment or operation of any manufacturing, mill, railway or other business or concern whatever, or,

(b) to exempt from taxation any manufacturing, mill, railway or other business or concern, to subscribe for stock therein or to guarantee the bonds, debentures or other securities thereof.

(2) If a council attempts to pass a by-law contrary to subsection (1) in regard to bonusing, a member of the council voting in favour of the by-law

(a) is guilty of an of fence and liable to a fine of not less than $\$ 50$ and not more than $\$ 100$ and in default of payment to imprisonment for a term not exceeding 60 days, and

(b) is disqualified for a period of 3 years from holding any municipal office.

(3) This section does not apply to

(a) an agreement in existence on June 1, 1968 between the municipality and any person,

(b) the disposal of any land or estate or interest in land in accordance with section 127 , or

(c) an agreement under section 354. 
Legislature. With the Minister's assurance in hand, Council passed a resolution on February 17 th providing for the requisite grants to the Stadium Society, ${ }^{3}$ which grants would be passed on to the football club in the form of rent abatements.

True to his word, the Minister put before Cabinet a draft regulation, which was passed on March $13,1986,{ }^{4}$ that provided:

Section $\mathbf{4 4 3}$ of the Municipal Government Act does not apply to a grant by a municipality to a non-profit organization.

Apparently as an expression of its gratitude to the citizens of Calgary for their unprecedented support in the ticket sale drive and to the members of Council who put their offices and reputations on the line, the Stampeder football team performed with unprecedented valour and skill on the playing field in the ensuing season and had its most winning year in a decade or more. Unfortunately, its winning record was for naught, the team's Grey Cup playoff hopes being dashed by their northern nemesis, the Edmonton Eskimos, in the first round of the 1986 playoffs.

Mention of the City of Edmonton begs description of the second controversial event having to do with the question at hand. Unlike Calgary, in the spring of 1986, Edmonton was experiencing no problems with its professional sports franchises, what with the local baseball club having won the league championship in 1984, the esteemed Oilers having won two consecutive Stanley Cups and seemingly on the way to their third, and the football Eskimos continuing to out draw every other team in the Canadian Football League. Instead and in keeping with its image as a no nonsense, businesslike, blue collar oriented community, the talk in Edmonton was of its new megamall and the impact it was having on an ever deteriorating downtown. To most observers the downtown was notable only for its boarded up store fronts, its numerous dusty parking lots serving as reminders of the National Energy Program and its dark and deserted streets once the office workers made their daily exodus to the suburbs.

The time had come to do something to entice the shoppers away from the submarines and rollercoasters at the Mall and into the downtown, while at the same time giving a transfusion to a local economy that was getting sicker day by day. New street lights and the modern facsimile of cobblestone, unibrick sidewalks, were a good start to improving the appearance of downtown, but much more had to be done. Enter those selfsame persons who many thought were, if not the cause, at least a major contributor to the deterioration of the downtown - the Mall builders. The proposal was to construct, in phases, a large underground parking lot, a

3. The resolution was purportedly passed under s. 213 of the Municipal Government Act which provides authority to a council to make grants to "community associations and community leagues that are providing recreation and community services to residents".

4. Alta. Reg. 176/1986. One cannot but question whether the $\mathrm{O} / \mathrm{C}$ was truly in respect of a "matter not provided for or insufficiently provided for" in the Act or whether it was in fact an amendment. If the latter view is taken the implications are obvious as to the vires of the regulation. Section $10(1)$ reads:

10(1) On the application of a municipality only the Lieutenant Governor in Council may make regulations providing for any matter not provided for or insufficiently provided for in this Act but any regulation so made ceases to have any effect after the last day of the next ensuing session of the Legislature. 
major department store, a shopping mall with hundreds of outlets and office and residential towers. The project was to be constructed on a two block area, at that time distinguished by an existing state of the art ultra modern, in the 1950's that is, Eaton's store surrounded on two sides by the largest no-mans land passing itself off as a parking lot in the downtown area. The problem was, due to the economic times, the financial viability of the project, to say the least, was not assured. Enter City Hall through one of the Mayor's task forces.

Protracted discussions and negotiations ensued between the principals of the City and the developer and their respective advisors, culminating in the passage by City Council, by a one vote margin, of the requisite land-use bylaw to accommodate the development and a resolution approving a master development agreement containing several schedules. In essence the agreement ${ }^{5}$ obligated the developer to commence construction, within a specified time, of the first phase of the project consisting of a one thousand car underground parkade, the department store and the retail mall, all to be built in accordance with the plans and specifications attached to the agreement. In return, the City was required to convey at a price of approximately $\$ 3.5 \mathrm{M}$, a sum approximating fair market value, certain lands it owned, including streets, sidewalks and alleys, that would be incorporated into the project. The developer was to pay approximately $\$ .5 \mathrm{M}$ of the purchase price up front, with the balance to be paid in ten years without interest. In addition, the City undertook to lease and operate the parkade for a forty year period ${ }^{6}$ at a fixed annual rent of $\$ 2.25 \mathrm{M}$, payable monthly, plus a "special additional rent", payable annually, for the first three years of the lease amounting to $\$ 5 \mathrm{M}$ in year one, $\$ 6 \mathrm{M}$ in year two and $\$ 8.5 \mathrm{M}$ in year three.

The article in the agreement dealing with the special additional rent contained a proviso that later turned out to be contentious in the legal sense as well as politically. The obligation to pay the special additional rent for a given year was subject to the proviso that the City would pay the lesser of the property taxes generated by the project, (excluding the taxes payable in respect of the parkade itself) and the special additional rent for that year. If the taxes were less than the special additional rent in the year, the difference between the two (the deficiency) would be carried over to the second year and added to the amount of the special additional rent payable for that year. If the taxes for the second year were less than the special additional rent for the year plus accrued deficiency, an amount equal to the taxes only would be paid and the deficiency would be carried over to the third year and so on. The unpaid special additional rent would stop accumulating

5. No attempt is made herein to give full particulars of the agreement, which contained 108 pages plus sketches and drawings.

6. By separate agreement, being a schedule to the master agreement, the City hired the development company as manager of the parkade at an annual fee of $5 \%$ of annual gross revenues.

7. The agreement contained a condition in respect of the special additional rent in the third year to the effect that $\$ 500,000$ of the $\$ 8.5 \mathrm{M}$ would be paid upon completion of each of the four office and residential towers contemplated in the project, should these components of the project not have been constructed by the third year of the lease. In other words, $\$ 2 \mathrm{M}$ of the $\$ 8.5 \mathrm{M}$ was payable only upon completion of the office and residential component of the Project. 
after the third year, at which point the accrued sum would begin to be reduced annually by payment of an amount equal to the property taxes collected for the given year. In this way the special additional rent would be paid off eventually, leaving just the fixed annual rental to be paid for the balance of the lease term.

Notwithstanding the obviously laudable results likely to flow from the two schemes described - salvation of civic pride, in the one case in the form of keeping a sporting franchise alive and, in the other, covering over a dusty parking lot - in each City a feisty citizen was sufficiently upset by what was perceived as an improper expenditure of public funds to take the matter over the heads of the duly elected representatives of the people and before a judge of the Court of Queen's Bench, the duly selected representative of the Governor General. In each case the challenge was based on an alleged violation of s. 443 of the Municipal Government Act.

Were it not for the third significant event in 1986 touching upon the topic at hand, it would be a relatively straight forward task for the writer to proceed to describe the litigation and their outcome and generally discuss the law of bonusing and tax exemptions as embodied in the aforementioned section. However, such was not to be the case since the Legislature, in its infinite wisdom, pulled the rug out from under the writer by repealing s. $443^{8}$ in the dying days of its 1986 session. This occurred after the litigation had, for all intents and purposes, been concluded. In light of that event, to proceed as planned might be seen as blowing out of proportion that which is little more than a footnote in the history of municipal jurisprudence in this Province. After all and because of the repeal, there is no longer a ban on bonusing and tax exemptions. Thus to belabour the point in this scholarly journal would be inimical to its avowed object of bringing before the bench and bar works directed at the resolution of contentious and difficult topical issues of the day. Madam Editor, although the writer will, but this once, mention the Charter of Rights and Freedoms, rest assured that which follows is nevertheless topical.

Simply put, the writer's thesis is that repeal of s. 443 has not given carte blanche to municipal governments to entice private development by means of grants, tax exemptions and other aid but, rather, municipal elected officials may not now expend public funds for private purposes any more than before the repeal of s. 443. Query, what then is the significance of the repeal? In the writer's opinion, whatever other bad things might happen to municipal politicians who squander public funds to entice private business, because of the repeal they will, at least, no longer face the prospect of being exiled into the political wilderness for three years and possibly subjected to a diet of fillet mignon in one of Her Majesty's hosteleries.

\section{THE LAW OF BONUSING AND TAX EXEMPTIONS APPLIED TO THE EATON CENTRE PROJECT}

Before elaborating on the proposition advanced, it is fitting and perhaps even imperative to an appreciation of the post s. 443 law to explore the law of bonusing as it existed up to August of 1986. This will be done in part in the context of the litigation arising out of the Eaton Centre Project.

8. Municipal Government Amendment Act, 1986, Bill 38, s. 26. 
The judicial pronouncement arising out of the Stampeder Football Club affair is not particularly informative on the substantive law of bonusing as the case never got to that point. No proceedings were ever commenced to challenge the validity of the resolution of February 17, 1986 which had authorized the grants to the McMahon Stadium Society. Perhaps the legal advice given was that such challenge would be futile in light of the regulation made under s. 110 of the Act. Alternatively, it may have been that the advice was to the effect that $\mathrm{s.} 443$ never did apply to grants and other aid accorded to non-profit organizations. ${ }^{9} \mathrm{Be}$ that as it may, proceedings by way of originating notice under Rule $410^{10}$ were commenced against the City of Calgary by one of the aldermen voting against the January 20 motion seeking answers to a number of questions including, inter alia, whether or not the motion of January 20th, "if passed, would have contravened s. 443.

The unusual nature of the application motivated the respondent to bring a counter-application under Rule 129 to strike the originating notice on the ground, among others, that the pleadings disclosed no justiciable issue in that all the questions posed were hypothetical in nature, the motion never having passed. The application to strike was granted and no appeal was launched. ${ }^{12}$ The court never got to the substantive law of bonusing.

The law of bonusing and tax exemptions was, however, canvassed by the Court of Queen's Bench in connection with the Eaton Centre Project. A local businessman filed an originating notice under Rule 410 for a declaration that parts of the agreement approved by City council on May 14,1986 and subsequently executed by the developers and the City were ultra vires s. 443 on their face. Specifically, it was alleged that: (i) the ten year interest free period for payment of the purchase price of the City lands amounted to a bonus contrary to $\mathrm{s.443}$; (ii) the special additional rent was in substance a tax exemption also contrary to s. 443; and (iii) if the special additional rent was not a tax exemption, it was nevertheless a bonus in violation of s. 443. The only evidence placed before the court was a copy of the agreement.

9. The writer has had occasion to research this point and has concluded that s. $\mathbf{4 4 3}$ had to be read subject to other provisions of the Act that conferred express authority to give grants and like aid to non-profit organizations. That is to say, grants to non-profit organizations were not encompassed by the section. If one examines the history of anti-bonusing laws one arrives at the conclusion that such laws were directed at the mischief flowing from giving preferential treatment to one private business entity at what is effectively the expense of another. Such potential mischief is not present when non-profit organizations are involved. See Gilbert v. Mun. of Metro Toronto (1985) 50 O.R. (2d) 654, 29 M.P.L.R. 184 (Div. Ct.) and Re Whitton and City of Ottawa [1967] 2 O.R. 509, 64 D.L.R. (2d) 265 (H.C.). The writer, however, cautions that the matter is not totally free of doubt and postulates later in this paper that this doubt was in part a motivation for repealing s. 443.

10. Alberta Rules of Court.

11. Recall that this resolution would have granted municipal monies to the non-profit McMahon Stadium Society, which in turn would have reduced the rental payable by the proposed new owners of the club, the group of private investors.

12. See the formal Order entered in the proceedings on June 5,1986 . While the Chambers judge gave oral reasons for judgment, it seems that no reporter was present and, therefore, no written record of the reasons for judgment exists. 
The learned Chambers Judge dismissed the application in its entirety and in the process delivered a short oral judgment that was transcribed. ${ }^{13}$ As to the interest free component of the agreement, the court found as a fact that the land sale had been for a "fair actual value" as authorized by s. 127 of the Municipal Government Act in that the interest that normally would have been payable was offset by the conditions of development imposed by the City Council on the developer. In any event, the City had advertised the fact of sale and the terms thereof as provided for in s. 127. Hence, since a disposition made in accordance with s. 127 was expressly excluded from the operation of s. 443 , there was no breach of that provision. ${ }^{14}$

The applicant argued that the proviso contained in the parkade lease connecting the special additional rent payments and the property taxes payable for the year that the special additional rent was due amounted to an indirect tax exemption. The contention was that the special additional rent was in reality an outright tax exemption dressed up in the form of a legitimate rent. In short, it was urged that the special additional rent clause was a sham to cover up the true intention of City Council, which was to confer a tax exemption. In response, the respondents argued that no tax exemption was involved since property taxes were payable for the land and improvements entailed in the project irrespective of anything that might transpire in connection with the parkade lease. Moreover, the position was taken that the special additional rent was no more than a means of accelerated recovery of the landlord's capital investment and that the connection between the special additional rent and property taxes was simply to assure that the City would not, during the years the special additional rent were payable, find itself in a negative cash flow position arising out of the operation of the parkade.

The chambers judge also dismissed the argument that the special additional rent was in reality a tax exemption, employing the following reasoning. First, there was no evidence adduced that the City was paying in excess of market value for its interest in the lease and, thus, it could not be inferred that the special additional rent payments were not a bona fide part of the parkade rental. Second, the obligation of the owner of the project to pay property taxes remained unabated. Third, the respondents had advanced a plausible explanation for the connection made in the lease between the special additional rent and the property taxes. Accordingly, the applicant had failed to discharge the onus on him of establishing the alleged illegality, whether in the nature of a bad faith exercise of power or otherwise.

The court went on to say that even if it had been established that the City was paying a premium for its leasehold interest in the parkade or that the land disposition was not in accordance with s. 127, the transaction was in any event not in contravention of s. 443 . The court reasoned that the

13. Tietzen v. City of Edmonton, unreported, 18 July 1986, J.D. of Edmonton, Action No. 8603-15394 (Alta. Q.B.).

14. There is a more complete discussion in this paper of the rights of a municipal council to sell land at less than fair market value where the disposition complies with s. 127 under the heading "Disposition of Land at Less than Fair Market Value". 
objective of city Council was not to confer a benefit on the developers to secure construction of the development in question but, instead, to advance its goal of downtown revitalization. During the chambers hearing the respondents had filed a number of by-laws and resolutions evidencing Council's efforts in the previous several years to revitalize the downtown. The respondents took the position that no illegal bonus could be found where the council in good faith acted under enabling provisions of the municipal legislation with the object of obtaining a public benefit beyond that which necessarily arises from the type of development encompassed by s. 443. The judge accepted this proposition. ${ }^{15}$ This last mentioned part of the Chambers judge's ruling begs a consideration of the case law pertaining to bonusing.

There are surprisingly few reported recent cases dealing with the subject of bonusing, most of them dating back to the late 1800's and early $1900^{\prime} \mathrm{s} .^{16}$ Perhaps one of the most influential cases in which the parameters of antibonusing provisions was considered in the context of municipal powers generally was that of Re United Buildings Ltd. and City of Vancouver. ${ }^{17}$ In that case the City council, at the behest of a developer, passed by-laws to close a lane and lease it to the developer at $\$ 1.00$ for twenty-five years, the land to be incorporated into the developer's building site. There was no contractual undertaking on the part of the developer to build. The action of council was pursuant to express provisions in the municipal enabling legislation authorizing council to close lanes and dispose of same. There was evidence that the developer had provided alternative means of vehicular movement and that the new pattern of traffic movement was beneficial to the neighbourhood and, possibly, an improvement over the situation previously prevailing. The relevant municipal legislation, the

15. Althouth not directly relevant to the topic at hand, it is noteworthy that the Chambers judge also dismissed the application on the ground that the applicant lacked status. The application was in essence a suit by a ratepayer to restrain the illegal expenditure of municipal funds. The case of MacIlreith v. Hart (1908) 39 S.C.R. 657 was relied on as authority establishing status. That case had held that a ratepayer action to restrain illegal municipal expenditures was an exception to the general rule that an applicant must show he has a particular interest or will suffer some injury or damage over and above that occasioned by the other members of the class from which he comes. The respondents took the position that Macllreith had to be read subject to Thorson v. A.G. of Canada (No. 2) [1975] 1 S.C.R. 138, 43 DL.LR. (3d) 1, Nova Scotia Board of Censors v. McNeil [1976] 2 S.C.R. 265, 55 D.L.R. (3d) 632, and Minister of Justice v. Borowski [1981] 2 S.C.R. 575, 130 D.L.R. (3d) 588, wherein the principle was established that the general rule requiring a special interest in order to confer status was displaced only in those circumstances where there was no other practical means open to anyone to challenge the impugned governmental action. The applicant having had available to him the remedy afforded by s. 414 of the Municipal Government Act to challenge a municipal by-law or resolution for illegality and not having availed himself of that remedy without any reasonable excuse, the exception to the general status rule could not operate. The Chambers judge agreed with the respondents' position.

16. See generally, Rogers, The Law of Canadian Municipal Corporations (2d ed.) at 863-872; Pike, Canadian Municipal Law (1929) at 349-354; Robson \& Hugg, Municipal Manual (1920) at 635-683; Biggar, Municipal Manual (1900) at 789-800, 955-962; Dillon, Municipal Corporations (5th ed.).

17. (1913) 3 W.W.R. 908 (B.C.S.C.), affd. (1915) 6 W.W.R. 1335 (P.C.). 
Vancouver Charter, contained a classic prohibition against bonusing except as authorized by a vote of the electors. ${ }^{18}$

The principal thrust of the challenge to the council's action was that it amounted to a bonus and the bonusing section had not been complied with since no vote of the electors had been conducted. At trial, the by-laws were upheld, the court finding that council had acted pursuant to express legislative authority having to do with lane closures and in so doing council was motivated by a desire to further the public interest in connection therewith. The court dismissed the argument that the consideration flowing from the developer, as evidenced by the nominal $\$ 1.00$ rent, demonstrated a bonus. The trial judge made the point that so long as a council gets what it "honestly thinks is a good quid pro quo this court has no right to call the other party's quid pro quo a bonus". ${ }^{9}$ The quid pro quo referred to was not the $\$ 1.00$, but the accommodation of traffic movement provided by the developer.

The case ultimately reached the Privy Council. The court there emphasized that the council had acted pursuant to an express power to close streets and in so doing was motivated, at least in part, by its perception that the closure of the street was beneficial to the public interest. The fact that steps taken in the public interest were accompanied by a substantial benefit specially accruing to a private business entity did not on that account render the steps the "giving of a bonus."

Keily v. City of Edmonton ${ }^{21}$ was another lane closing case. A company proposed to build an elevator, grist mill and other buildings on a particular site and in the course thereof would build over an existing public laneway. An application was filed with the City council to close the lane and transfer it to the company in return for the company providing as an alternative lane an easement on an adjacent strip of land it owned. The council passed the requisite by-laws to close and transfer the lane and thereby accommodate the development in question. While council's actions were not challenged head-on as amounting to a bonus contrary to an express antibonusing section in the municipal legislation, the case dealt with the bonus question tangentially. Citing the United Buildings case, Ford J. expressed the opinion that so long as council was acting in good faith under enabling provisions and was doing so to achieve the public benefit, it was not for the court to launch into an examination of the adequacy of the benefit. It was

18. Vancouver Incorporation Act, 1900.

194. Notwithstanding any law to the contrary, a Municipal Council shall not have the power to grant to any person or corporation any particular privilege or immunity or exemption ... or give any bonus or exemption from any tax, rate, or rent ... unless the same is embodied in a by-law which, before the final passage thereof, has been submitted to the electors of the municipality ... and which has received the assent of not less than three-fifths in number of the electors ...

19. Supra n. 17 per Clement J. at 910.

20. Id. per Lord Sumner at 1340-41:

But though the operation of a by-law benefits one or more persons more than others, it does not follow that by enacting it a corporation must be taken as "giving a bonus" ... nor can a by-law be said to be outside the powers conferred ... merely because steps taken in the public interest are accompanied by benefit specifically accruing to private persons.

21. [1931] 1 W.W.R. 365 (Alta. S.C.). 
stated that the court should only intervene if it was demonstrated that the benefit was a mere sham so that in truth there was no benefit at all accruing to the public. If that be the case, it could be said that the council was not acting in the public interest but solely in the private interest. ${ }^{22}$ The court found on the evidence presented that the council had acted bona fide in the public interst and, thus, no bonusing was involved.

In Ward v. City of Edmonton ${ }^{23}$ council passed certain resolutions awarding grants totalling $\$ 25,000$ to a variety of non-profit organizations, which organizations provided such things as medical services and aid to the poor within the community. At that time the enabling legislation, The Edmonton Charter, ${ }^{24}$ contained no express power to give grants to charitable and like organizations. ${ }^{25}$ The resolutions were challenged as amounting to bonuses contrary to the section of the Charter prohibiting, absent electoral consent, the giving of a bonus or other aid to secure development. Since there had been no vote of the ratepayers, it was claimed that the council's actions were ultra vires. The court held that the "peace, order and good government" clause of the Charter conferred authority on council to make grants of the type in question and that the grants were not caught by the Charter's bonusing provisions.

More particularly, the Court defined a bonus as a grant given for the sole purpose of inducing or enticing the establishment or continuation of various kinds of private business undertakings within the community. In a bonus situation, the court said that the sole benefit accruing to the municipal corporation is the increase in tax base and increased business activity generated by the establishment of the undertaking. The court went on to say that what distinguished a grant of the type in issue from a bonus was that the consideration or benefit flowing to the municipality in the case of a grant was of a totally different character. In the case of a grant, the quid pro quo for the grant is the partial release of the municipality from its statutory obligations to provide health services, aid to the poor and the like. The case, therefore, suggests that if there are motivations beyond those of securing the establishment of an undertaking and if the benefit derived by the municipality goes beyond that which is inherent in the securing of the undertaking, no bonusing is involved.

In all of the cases in which the court found there existed an illegal bonus or tax exemption, two components were present. First, the municipal council was either not purporting to exercise some substantive municipal power conferred under the enabling legislation or, if it was, it was found to be a mere sham. Second, the only consideration or benefit flowing to the municipality, aside from the benefit that naturally arises out of the establishment of any business enterprise, was nominal in nature.

22. For the proposition that a court may not substitute its opinion on the question of what is sufficiently in the public interest for that of the municipal council see also Kuchma v. Rural Municipality of Tache [1945] S.C.R. 234 at 243; Metropolitan Stores Ltd. v. Hamilton [1945] 4 D.L.R. 745, [1945] O.R. 590 (Ont. H.C.); Re Cambridge Leaseholds and Toronto [1973] 3 O.R. 395 at 395-400 (H.C.); and Summer Village of Sundance Beach v. W.A.W. Holdings Ltd. (1981) 117 D.L.R. (3d) 351 at 359-361 (Alta. C.A.).

23. [1932] 3 W.W.R. 451 (Alta. S.C.).

24. S.A., 1913, c. 23.

25. Today, of course, there is such express power contained in s. 212 of the Municipal Government Act. 
To illustrate, in Re Campbell and Village of Lanark ${ }^{25}$ a by-law was passed and an agreement signed to give $\$ 4,000$ to a businessperson to enable the rebuilding of a flour mill that had previously burned down. At a town hall meeting prior to the passage of the by-law and the signing of the agreement, the matter of anti-bonusing legislation contained in the operative municipal legislation was discussed. Observations were made by some attending that a way of "getting around it", the anti-bonusing legislation, was necessary. A decision was made to put a provision in the agreement whereby the mill operator was to grant to the village "space in the said mill for placing and operation of such machinery as the municipal corporation may decide to place therein for the purpose of electricity and lighting." Evidence was presented to the court that the village had not explored the question of costs to it of using the mill for electricity generating and had taken no other investigative steps whatever of the kind that usually accompany such a decision. The court held that on the evidence presented it was clear that there was no intention to use the mill for public electricity purposes and that this was put into the agreement as a way of getting around the anti-bonusing legislation. The court found no consideration, beyond the undertaking to build, for the $\$ 4,000$ payment since the term respecting the electricity generating was a sham. Thus, the scheme was found to constitute a bonus.

In People's Milling Company and Council of Meaford ${ }^{27}$ the municipal legislation, unlike that in $\operatorname{Re}$ Campbell, expressly authorized an exemption from taxation of a "manufacturing establishment". The town leased some land to the company and in the lease the company undertook to use the land only for carrying on the business of a flour and grist mill and "the general grain trade". Council passed a by-law expressly exempting all the company's property from taxes. The court held this to be an illegal tax exemption because the legislation restricted exemptions to manufacturing businesses and a "general grain trade" was not such a business. There was nothing motivating the council except the desire to secure the establishment of the work and no benefit was going to accrue to the municipality and its residents other than that which naturally flowed from the construction and operation of the work.

In Re Lamb and the City of Ottawa ${ }^{28}$ the City entered into a lease of land it owned to enable the lessee, a private business enterprise, to construct a building thereon for its use. The lease called for a $\$ 500,000$ rental but expressly exempted the building from taxation. The court held that the tax exemption was "aid by way of bonus", contrary to the legislation in place, there being no municipal purpose other than to secure the construction of the building.

Closer to home, in Re Loiselle and Town of Red Deer ${ }^{29}$ the town passed by-laws to close a portion of a street and convey it to a company for $\$ 1.00$, purportedly pursuant to express authority in the municipal legislation

26. (1893) 20 O.A.C. 372 (Ont. C.A.).

27. (1886) 10 O.R. 405 (Q.B.).

28. (1904) 4 O.W.R. 408 (Ont. S.C.).

29. (1907) 4 W.L.R. 42 (Alta. S.C.). 
authorizing closing and selling of streets ${ }^{30}$ The court found that there was never an intention that even the $\$ 1.00$ be paid and the company "did not intend to bind themselves to do anything in return for this land". The court also found that the closing was solely to accommodate the company and no one else and held the transaction "was a pure gift" and, thus, a bonus contrary to the legislation. ${ }^{31}$

The only recent reported Alberta case on the subject of bonusing and tax exemptions is that of Northern Alberta Agribusiness Ltd. v. Town of Fahler..$^{32}$ The Town approached the company asking it to construct and operate an alfalfa plant on land adjacent to the Town, which the Town would then annex. The Town also advised the company that it was prepared to give the company a tax abatement and subsequently passed a resolution stating:

\footnotetext{
Be it resolved that Council grant a tax abatement to Northern Alberta Agribusiness Limited to the extent of the Municipal portion of the taxes which may be levied, to an equivalent amount that was granted to Falher Alfalfa Limited, regardless [of] the number of years this amount is realized in.
}

There was no contract entered into between the parties. The plant was built in due course. It appears that the Town took the position afterwards that it was entitled to collect taxes. The company brought an action for a declaration that it was not obligated to pay taxes in light of the resolution that had been passed. The court held the resolution to be a tax exemption in violation of s. 443 and, therefore, void..$^{33}$

The golden thread that runs through the cases is that a council action is not a bonus when the council acts bona fide and in furtherance of some substantive power conferred upon it in its enabling legislation with the intention of achieving a benefit for the municipal corporation and its citizens that is beyond the benefit that is inherent in or naturally arises from any business undertaking that establishes itself because of the council action. No bonus is involved even though, as a direct result of the municipal action, an undertaking is established and the benefits accruing to the person or entity establishing the undertaking are well beyond those benefits accruing to others.

On the other hand, where the circumstances of the transaction are such as to disclose either that the council was not acting pursuant to some express or necessarily implicit power granted in the enabling legislation, as in Northern Alberta Agribusiness, or where, purporting to act under some such express power, the fact of the matter is that the only real benefit accruing to the municipality is the establishment of the work, then the council action is a bonus, as in the Campbell and Loiselle cases. In the latter situation evidence that no real benefit accrues to the municipality other than the establishment of the work is taken as proof that there never was a

30. S.A. 1906, c. 30, s. 2.

31. N.W.T. Ord. 1905, c. 7, s. 215.

32. (1980) 14 Alta. L.R. (2d) 97 (Alta. Q.B.).

33. See also In Re Inglis and City of Toronto (1905) 9 O.L.R. 562 (Div. Ct.); Keay v. City of Regina (1912)6 D.L.R. 327 (Sask. S.C.); Re Foxcroft and City of London (1927) O.L.R. 209 (C. P.); Re Edwards and Town of Brampton [1933] O.W.N. 635 (H.C.); Town of Listowel v. Listowel Casket Company Ltd. [1943] O.W.N. 358 (H.C.); and Re Immobiliere Viger Ltee and Laurent Giguere Inc. [1977] 2 S.C.R. 67. 
bona fide intention to exercise the express power under which the council purported to act. In such a case, the council is taken as having acted for the sole purpose of enticing the work's establishment. In other words, the ostensible exercise of the express power is a mere sham to cover up the true intention of council, to secure the work.

However, the evidence of lack of any benefit to the municipality and its citizens other than that arising naturally from the establishment of the work per se must be compelling. If there is some evidence of additional benefit the courts are loathe to characterize the transaction as a sham in the face of the principle that the adequacy of the benefit is for the municipal council to determine and not for the courts.

In the case arising out of the Eaton Centre Project, the judge applied these principles and rejected the argument that there was an illegal bonus. Firstly, in entering into the parkade lease the City council was acting under express or necessarily implicit authority that empowered it to do so. ${ }^{34}$ Secondly, the recitals in the agreement under attack contained numerous references to the City's objective of revitalizing downtown. This objective too is a legitimate municipal purpose. ${ }^{35}$ Thirdly, council was of the opinion, reasonably held, that its participation in the Eaton Centre Project would serve the objective of downtown revitalization and, hence, provide benefits to the City and its residents going far beyond those benefits inherent in the construction and operation of the Project when viewed in isolation. Finally, there was no evidence before the court that would warrant it finding that the entire transaction was wrapped in a deceptive package and that the true and sole motivation of council was to benefit private developers at the expense of the public purse to secure the construction of the project in order only to reap the benefits of the jobs that it would create, the taxes it would generate and the increased business activity that would follow. In other words, there was no basis upon which the court could conclude that a seemingly valid exercise of power for municipal purposes was in truth exercised in bad faith.

\section{THE HISTORY OF BONUSING AND TAX EXEMPTION LEGISLATION IN ALBERTA}

To what extent has repeal of s. 443 modified the law reflected in the Eaton's Centre case? In the writer's view, very little. This assertion is based in part on an examination of the historical antecedents to s. 443 and in part on some basic principles of municipal law.

An examination of the history of s. 443 yields the proposition that legislation specifically addressing bonusing and tax exemptions was, in its inception, enabling as distinct as from prohibitory in nature. It gradually

34. See Municipal Government Act supra n. 2 ss. 112, 126, 130, 132, 171.4(d), 171.5(6)(b) and 354. These sections establish that provision of public parking is a legitimate municipal purpose. See also Magee v. City of Calgary [1979] 6 W.W.R. 404 at $412-413$ (Alta. Q.B.) and Re Smuck and City of St. Thomas (1981) 32 O.R. (2d) 698 (S.C.), affd. 35 O.R. (2d) 160 (C.A.) wherein the courts held that entering into transactions for the purpose of securing public parking is a legitimate exercise of municipal power.

35. See Municipal Government Act, supra n. 2, ss. 112, 132 and 171.1 to 171.9 and also the Planning Act, R.S.A. 1980, c. P-9, ss. 2, 61-63 and 65-67. 
evolved, at least in Alberta, to amounting to no more than a penalty section for a specific type of ultra vires municipal council action.

The basic and fundamental principle in municipal law is and always has been that municipal councils, being creatures of statute, have only those powers that are expressly conferred together with those which "are necessarily or fairly implied or incidental to the express powers". ${ }^{36}$ Right from the beginning of municipal government in Canada, this principle has applied to all municipal actions including the expenditure of municipal funds or other forms of activity involving the depletion of municipal assets. $^{37}$

The transfer of municipal resources to a private business enterprise for its use and benefit and for the sole purpose of enticing the enterprise to establish itself or to remain in operation in the community, although in a general sense the enterprise may be beneficial to the community due to its economic spin-off effects, could in no sense be construed as a "municipal purpose" as that concept has been generally understood. That being the case, early provincial legislatures determined as a matter of policy that it would be beneficial if municipal councils were expressly given the legal authority to attract the establishment within their corporate boundaries of railways, mills and like industries. The assumption was that, in return for the short-term investment of its resources, a municipality would reap benefits for years to come in the form of increased employment, increased tax assessment and increased overall business activity, all leading to prosperity for the municipality and its citizens. The result was passage of enabling legislation dealing expressly with tax exemptions and bonusing but limiting the authority to confer such benefits to those cases where the assent of the electors was first obtained. ${ }^{38}$

However, bonusing and tax exempting enabling legislation was not universally applauded, even in the early days. The sentiments expressed by a judge in one case sums up the attitude of many: ${ }^{39}$

Exempting the property of one person from taxation ... is an invidious one, to be watched with jealousy, and exercised strictly.

Bonusing enabling laws were viewed as invidious because: ${ }^{40}$

(i) they tended to give the recipient of the largesse a competitive advantage over rival businesses at the very expense, in part, of the rivals;

(ii) they created unseemly bidding wars among municipalities falling over one another to give the best deal;

(iii) they were inherently discriminatory;

(iv) they fostered graft and corruption and;

(v) attempts to nourish a business by the artificial stimuli of bonuses and tax exemptions as often as not ended in disappointment and loss, the business ultimately failing.

36. See Rogers, supra n. 16 at $350-369$ and cases cited therein.

37. Board of Trustees of Eltham S.D. v. Langston [1923] 3 W.W.R. 641 (Sask. C.A.).

38. See Robson and Hugg, supra n. 16 at 635-683.

39. People's Milling Co. v. Council of Meaford, supra n. 27 at 413.

40. See e.g. Biggar, supra n. 16 at 792 . The Americans have similar anti-bonusing dictrines as prevail in this country. See generally, Antieu, Municipal Corporations Law Vol. 2, c. XVA and Thyne, Municipal Law c. 15. 
These types of concerns led to amendments by stages resulting in provisions like the former s. 443.

The first legislation dealing with bonusing and tax exemptions governing the territory that is now Alberta appeared in the Northwest Territories Ordinances of $1883^{41}$ as follows:

25. The Council of any municipality may pass by-laws for

(23) The granting of bonuses to manufactories, mills, railways, or any works of a public nature, subject to the ratification by the people as hereinafter provided for;

(24) Exemption from taxation for the then current year;

(25) Exemption from taxation for a longer period than one year, subject to ratification by the people as hereinafter provided for.

These provisions remained intact and operative up to the date that Alberta entered Confederation in $1905^{42}$ and remained in effect thereafter by operation of the Alberta Act ${ }^{43}$ until altered by the Alberta Legislature.

Bonusing and tax exemption provisions materialized in the first Alberta Rural Municipalities Act, ${ }^{44}$ reading thusly:

197. No council of any municipality shall have power -

1. To grant a bonus or any other aid to any person, company or corporation for the construction, establishment or operation of any manufactory, mill, railway, or any other business or concern whatever either within or without the municipality;

2. To exempt from taxation any such manufactory, mill, railway or other business or concern nor to subscribe for stock in or to guarantee the bonds, debentures or other securities thereof.

Inexplicably, the first Towns Act, ${ }^{45}$ passed in the same session of the Legislature, was worded differently:

164. Notwithstanding anything contained in the next preceding section or elsewhere in this Act no town shall have the power to bonus in any manner, exempt from taxation, acquire stock in or guarantee the payment of any bonds or debentures issued by any railway company.

The "preceding section" referred to in s. 164 contained some ninety subsections detailing those subject matters over which a municipal council could pass by-laws. There was no reference to bonusing in those subsections and the only reference to tax exemptions was a carry over of the provision in the Ordinance authorizing exemption from taxation for the current year.

In 1913 the Towns Act was amended ${ }^{46}$ to read like the Rural Municipalities Act. In the second session of the 1913 Legislature, the bonusing provisions of the Towns Act were again amended, ${ }^{47}$ this time adding a penalty provision at the end of s. 164 as follows:

Provided also that if the council of any town attempt to pass a by-law contrary to the above provisions in regard to bonusing, each member of the council voting in favour of

41. An Ordinance Respecting Municipalities, No. 2, 1883.

42. Municipal Ordinance 1905, O.C. c. 70 , ss. $95(38)$, (39), and (40).

43. 4 - 5 Edward VII, c. 3, s. 16. This section provides, inter alia, that all laws, orders and regulations operative in Alberta on the date of the Alberta Act coming into force were to remain the law in Alberta until modified by that legislative body having constitutional authority over the particular subject matter involved in the law.

44. S.A. $1911-12$, c. 3, s. 197.

45. S.A. $1911-12$, c. 2 , s. 164.

46. S.A. 1913 (1), c. 8 , s. 10.

47. S.A. 1913 (2), c. 22 , s. 7. 
such by-law shall be liable on summary conviction to a penalty not exceeding one hundrd dollars exclusive of costs, and such members of council shall be disqualified from holding any municipal office for a period of two years.

There was no corresponding amendment to the Rural Municipalities Act.

The penalty provision in the Towns Act bonusing section disappeared upon repeal of the Towns Act and passage of the Towns and Villages Act of $1934,{ }^{43}$ but the express prohibition against bonusing and tax exemptions was carried forward.

The first City Act, ${ }^{49}$ passed in 1951, contained an identical bonusing and tax exemption section to that found in the Rural Municipalities Act and the Towns and Villages Act but it went on to provide for a penalty in respect of offending councillors similar to that in the now repealed s. 443. The disqualification and summary conviction penalties did not apply to councillors of rural municipalities, towns, or villages until passage of the Municipal Government Act in $1968,{ }^{30}$ at which time the bonusing and tax exemption provisions of the City Act were carried forward and applied to all municipal government units in the Province.

It is noteworthy that the Alberta Legislature did revive for some years an express tax exemption power through the medium of fixed assessments. In 1925 the Legislature passed an enactment titled the Industries Assessment Act $^{\text {s1 }}$ which conferred on councils of a city, town or village (rural councillors presumably not being sufficiently trustworthy to be given the power) jurisdiction to pass by-laws, on the vote of three-quarters of the members of the council, "fixing the assessment of property of any person carrying on or proposing to carry on, within the area of the municipality, any industrial establishment or manufactory, on such terms and conditions as the council may deem proper"..$^{22}$ The power to fix the assessment, which was not to be fixed at less than $10 \%$ of actual value and not to be for longer than 20 years, applied only to improvements and not the land itself. ${ }^{33}$ There was one other significant rider. The by-law was only operative upon securing the assent of two-thirds of the qualified electors who voted on the matter. ${ }^{54}$

The Act underwent several amendments during its currency so that by the time of the 1955 Statute Consolidation,,$^{35}$ the assessment was to be fixed at a figure no less than $25 \%$ of the value of improvements and, in addition to requiring the affirmative vote of three-quarters of all the members of council and the assent of two-thirds of the electors, it required the approval

48. S.A. 1934 , c. 49 . The Villages Act, R.S.A. 1922, c. 109 , s. 77 , which was replaced by the Towns and Villages Act, contained bonusing and tax exemptions prohibitions as well.

49. S.A. 1951, c. 9, s. 713. To this point Alberta cities had been created and governed by special acts. These special Acts, or Charters as they were termed, went through evolution in respect of bonusing and tax exemptions similar to legislation governing rural municipalities and towns except that the express power to grant bonuses and tax exemptions upon securing the assent of the electors remained part of the powers of city councils long after it was taken away from councils of other local government units.

50. S.A. 1968 , c. 68 , s. 426.

51. S.A. 1925 , c. 10 .

52. Id. s. 3(1).

53. Id. ss. 3(2) and 4.

54. Id. s. 5.

55. R.S.A. 1955 , c. 156. 
of the Minister of Municipal Affairs. Clearly the legislation contained adequate checks and balances. One other amendment of note occurred in the interim; namely, no fixed assessment by-law was to be passed in respect of a business that had removed itself from one city, town or village and had relocated into the municipal government unit contemplating the fixed assessment by-law..$^{56}$ In other words, it was not permissible for one city to steal a business from another, but taking it from a rural municipality was fine. The Industries Assessment Act receded into oblivion with its repeal in 1957. 57

\section{THE PURPOSE AND EFFECT OF REPEAL OF S. 443}

In the writer's opinion, the history of bonusing and tax exemption legislation in this Province is supportive of the proposition that the repeal of s. 443 does not have the effect of rendering bonusing and tax exemptions by municipal councils lawful in Alberta. As previously stated, bonusing and tax exemption legislation was in its genesis enabling in nature. Over time the express power to confer bonuses and tax exemptions was taken away and any attempts to confer them was made subject to penalty. The proposition then, simply put, is that the intent of the Legislature in repealing s. 443 was not to enlarge the powers of municipal councils to enable them to swim into the turbulent waters that characterize bonuses and tax exemptions. Instead, the purpose was twofold. First, the intent was to remove the patent ambiguities and seeming conflicts between s. 443 and other sections of the Municipal Taxation Act and Municipal Government Act empowering municipal councils, in the case of the former Act, to forgive taxes and confer limited exemptions and, in the case of the latter, to provide aid and assistance to non-profit and other organizations whose objective is the enhancement of the interests of the community. ${ }^{58}$ Second, the Legislature decided that, as a matter of policy, the illegal expenditure of municipal funds by a council to induce the location or continued operation of a business enterprise in the community ought not to be accompanied by the sanctions provided for in s. 443. While it may not be admissible in a court of law to establish the intent of the Legislature in repealing the section in question, the circumstances out of which the repeal arose, the steps taken in Calgary by the Council to save the City's football club, clearly suggest that the writer's perceptions are accurate.

56. Id. s. $5(3)$.

57. S.A. 1957, c. 33.

58. As to the Municipal Taxation Act see for example s. 93(13), infra n. 63; s. 104, infra n. 64; s. 105, infra n. 65; and s. 106, infra n. 66. As to the Municipal Government Act, supra n. 2, see s. 115 which provides:

115. A council may pass a by-law authorizing the making of an agreement with any corporation that has as one of its objects the advancement of the interests of the municipality and its residents and that is not incorporated for the purposes of acquiring gain for its members, when in the opinion of a majority of the members of the council, the objectives of the agreement will benefit the municipality and its residents.

See also, the Municipal Government Act, supra n. 2 s. 212 (grants to charitable, religious, educationa, cultural, athletic and like organizations); and s. 213 (grants to community leagues and similar organizations for recreational purposes). Two sections of the Act give express power to grant aid to businesses; i.e. s. 205 (grants to doctors and dentists to induce establishment of medical and dental practices in the community) and s. 257 (grants to veterinarians to induce establishment of a veterinarian practice in a rural municipal district). 
In the final analysis, municipal schemes which involve tax exemptions, grants or other forms of valuable municipal aid that are designed with the sole objective in mind of encouraging private businesses and developments to locate in the community, to the extent they are not expressly or by necessary implication authorized by the municipal enabling legislation, are as illegal today as they were before the repeal of s. 443 .

\section{THE CURRENT STATUS OF TAX EXEMPTION POWERS}

To explore this theme further, consider the matter, first, of tax exemptions. By repeal of s. 443 there is no longer an express provision in the Municipal Government Act ostensibly prohibiting tax exemptions. Does it, therefore, follow that the Legislature intended by the repeal that a council be free to confer such exemptions? The answer lies in the Municipal Taxation $\mathrm{Act}^{59}$ and the general principle that a public authority, such as a municipal council, must not discriminate in the application of its powers, except to the extent expressly authorized by the legislation conferring the powers.

The regime set up by the Municipal Taxation Act contemplates that all property within a municipality be subject to assessment and taxation except as provided for in that Act or any other statute. ${ }^{60}$ The Act sets out

59. R.S.A. 1980 , c. M-31.

60. This proposition emerges from an examination of the following sections of the Municipal Taxation Act:

3(1) Except as provided by this or any other Act, all property that is situated in a municipality is subject to assessment and taxation by the municipality.

4(1) Every year, each municipality shall prepare an assessment roll setting forth the assessed value of all assessable property within the municipality as established by the assessor in accordance with this Act.

27(1) In every municipality the assessor shall, not later than December 31 in each year, assess for taxation purposes in the next following year all assessable property in the municipality.

93(1) The council shall in each year, by by-law, authorize the municipal secretary to levy on the assessed value of all assessed property shown on the assessment roll, a tax

103. Subject to this Act, the municipal and school taxes of a municipality shall be levied on the assessable land and improvements

$$
\text { ... }
$$

108(1) The municipal secretary shall on or before the date in each year fixed by the council prepare a tax roll and shall proceed to collect the taxes specified on it.

110(1) A person who is the owner or purchaser of any assessed land, improvement... shall pay taxes on the assessed value thereof at the rates lawfully imposed thereon

113(1) The municipal secretary shall either mail to each taxable person or deliver to an adult person at the residence or business office of the person taxed one notice during the year with respect to each parcel showing

(f) the total taxes due in respect of the assessed business or property. 
with particularity the property that is absolutely exempt from assessment, ${ }^{61}$ that which is exempt from assessment at the option of the local council, ${ }^{62}$ and that property, while assessable, which a council may nevertheless exempt from taxation per se. ${ }^{63}$ In addition, a council is given power to compromise payment of tax arrears, ${ }^{64}$ to cancel uncollectable arrears ${ }^{65}$ and, where it considers it equitable to do so, to cancel or refund all or any part of a tax levy. ${ }^{66}$ The latter, however, applies only in respect of accrued taxes and confers no authority on a council to cancel future tax levies ${ }^{67}$ Additionally, the Municipal Tax Exemption Act ${ }^{68}$ provides a vehicle for exempting property of a non-profit corporation from assessment and taxation otherwise caught by the Municipal Taxation Act. The power of exemption under tnat Act, however, is exerciseable only by the Local Authorities Board on application duly made.

In the writer's view, any exemption from assessment or taxation not expressly authorized by the Municipal Taxation Act and other legislation like the Municipal Tax Exemption Act would be illegal as a noncompliance with the taxing legislation, whether or not there exists a provision like the former s. 443. Taxation enabling legislation not only imposes a power on a council to levy taxes, it imposes a duty to do so except as otherwise expressly provided. ${ }^{69}$ This flows from the general proposition that the burden of taxation must fall evenly on all ratepayers and that no one ratepayer is to be given favourable treatment as such would, of

61. Id. s. 24. This section contains a long list of exempt property but does not include in that list the land and improvements of a commercial undertaking save one engaged in farming.

62. Id. s. 25 . This section pertains to the property of agricultural societies, non-profit organizations providing community facilities, nursing homes, summer camps, veterans associations and educational institutions where the property is used for residential purposes.

63. Id. s. 93(13). This subsection authorizes a municipal council to exempt machinery, equipment and working tanks used in processing or manufacturing or in the production or transmission of natural resources. In Northern Alberta Agribusiness v. Town of Fahler, supra n. 32, it was held that a resolution to the effect that "council grant a tax abatement to Northern Alberta Agribusiness Ltd"' did not fall within the provisions of s. 93(13) and was, since no other exempting provision of the Municipal Taxation Act applied, an exemption contrary to s. 443. It is submitted that the same result would have prevailed even absent s. 443.

64. Id. s. 104:

104. A council may pass a resolution for the purpose of compromising payment of arrears of taxes on any terms that may be agreed on.

65. Id. s. 105:

105. A council may pass a resolution for the purpose of cancelling arrears of taxes that appear on the assessment and tax roll and that are no longer secured by a charge against land or other property and no longer collectible from the person taxed.

66. Id. s. 106:

106. A council may with respect to a specific property or business pass a resolution in any case where the council considers it equitable to do so

(a) to cancel or refund all or any part of a tax levy, ...

67. In the Eaton Centre agreement and in a development agreement relating to the Manulife Phase II project in downtown Edmonton, there appear terms whereby the City Council undertakes to give good faith consideration to an application by the developer for forgiveness of taxes under s. 106. For obvious reasons, the clauses were carefully crafted to ensure that the discretion conferred on Council under s. 106 was in no way fettered.

68. R.S.A. 1980 , c. M-30.

69. See e.g. Tellier v. St. Hyacinthe [1935] S.C.R. 578, [1936] 1 D.L.R. 257. 
necessity, be at the expense of other ratepayers. ${ }^{70}$ Thus, any claim to an exemption or any measure to confer an exemption is strictly construed against a result that would provide the exemption. ${ }^{\prime \prime}$ In short, a tax exemption not expressly authorized is illegal. Hence, the authority that a municipal council has for relieving against the payment of property tax is that limited power contained in the legislation referred to. Any measures that are taken that are not in conformity with that legislation are beyond a council's jurisdiction. Repeal of s. 443 does not alter that fact.

\section{DISPOSITION OF LAND AT LESS THAN FAIR MARKET VALUE}

What about other forms of municipal aid to a business to secure its continuation or location within the community? ${ }^{22}$ Municipal aid, other than tax relief, can take two forms. On the one hand, it may be that type of aid which involves a depletion of municipal assets. On the other hand, it may be that type which entails inducing a business to locate in a municipality through means that do not affect the municipality's balance sheet. Examples of the latter would include such things as expediting the permit application process and waiver of planning regulations. ${ }^{3}$ Only the first mentioned type of aid will be addressed.

It is appropriate to first deal with aid to a private business involving the disposition of municipal property to the business. One of the most obvious and ofttimes readily available ways of inducing a business to locate in a municipality is to provide the business, at less than fair market value, with a site on municipally owned lands. Section 127 of the Municipal Government Act provides two alternative ways of lawfully achieving such a result.

The general rule in $\mathbf{~} 127$ is that a municipal council may only dispose of an interest in its lands at fair market value. One of the exceptions to this principle is that a council may dispose of an interest in its land at less than market value where it first advertises its intention to do so and where, subsequent to the advertisement, no petition pursuant to ss. 6 and 324 of the Act, calling for a vote on the disposition by the proprietory electors, has been filed with the municipal secretary. The prospect of a plebiscite could be a deterrent to a council disposing of lands at less than fair market

70. See e.g. Cogswell v. Holland (1889) 21 N.S.R. 155 at 161 ; aff'd 17 S.C.R. 420 wherein it was stated: "It cannot . . . be disputed that the principles of equality and uniformity should also pervade all local taxation which ought to be uniform on the same class of subjects, and assessed upon all property according to its proper valuation, and . . . a court should hesitate to give any interpretation to a taxing act which would disturb that equality or give any advantages or exemptions in respect of any particular portion of the property within the district over which the assessment extends unless it is clearly warranted by the statute imposing the tax."

71. See e.g. Pringlev. Stratford (1909) 20 O.L.R. 246 (C.A.); Becker v. Toronto [1933] O.R. 635, [1933] 3 D.L.R. 428, reversed on other grounds [1933] O.R. 843, [1933] 4 D.L.R. 736 (C.A.); and McPhedran and Cleland v. Toronto [1932] O.R. 198, [1932] 2 D.L.R. 202 (C.A.).

72. For purposes of this discussion, only privately owned, for-profit business enterprises will be considered. The authority of municipal councils to bestow monies upon non-profit organizations is, by the express terms of the Municipal Government Act, considerably broader. See eg. Municipal Government Act, supra n. 2 at ss. 115, 212, 21 3, and 354. See also n. 58.

73. An example would be the reduction of parking requirements otherwise provided for in municipal plans and by-laws in respect of a new commercial development. 
value. However, inasmuch as the petition calling for a vote must contain the signatures of proprietory electors equal to at least five percent of the total population of a municipality having a population of one thousand or more and, further, such petition has to be submitted within twenty-two days of the appearance of the first advertisement in the local newspaper, at least in the larger local government units, the threat of a vote is more apparent than real. ${ }^{74}$

In any event, a municipal council seeking to dispose of real property at less than market value has another course available to it that does not entail the risk of a plebiscite. Section 127(2)(b) permits a council to sell an interest in land at "fair actual value". That phrase is defined as "market value less the value as determined by the council of any conditions imposed on the development of the land."' The latitude this affords a council is illustrated by the recent case of Spruce Grove v. Yellowhead Regional Library Board. ${ }^{76}$

In that case the plaintiff had transferred certain of its lands, with a market value of $\$ 110,000$, to the defendant for the sum of $\$ 1.00$ in return for an undertaking by the defendant to construct a regional library on the site, failing which the land was to be returned. After the defendant had honoured its undertaking to build, the plaintiff attempted to recover the land through a court action based on the theory that the disposition it had made was ultra vires the Municipal Government Act because it was in contravention of s. 127 .

The court unequivocally rejected the plaintiff's contention, holding that the undertaking to build the library constituted sufficient value to make up the difference between the market value of $\$ 110,000$ and the $\$ 1.00$ actually paid so that the sale was at "fair actual value" as defined in the section. Thus, the transaction was authorized by $s .127 .{ }^{n}$

The principle of this case is doubtless applicable to any disposition at less than fair market value by a municipal corporation to a developer, provided conditions relative to development of the land are attached to the disposition. ${ }^{78}$ Moreover, the outcome in this case demonstrates that it would be very difficult indeed for an objector to satisfy a court that a disposition to a developer was at less than "fair actual value", so long as

74. For example, in a city of 500,000 population, at least 25,000 signatures of proprietory, as distinct from ordinary electors, must be obtained. A proprietory elector is an elector whose name appears on the property tax assessment roll (including an elector who owns shares in a corporate farm) or an elector who pays a mobile unit license fee. See Municipal Government Act, supra n. 2 at ss. 1 (u) and 324.

75. Municipal Government Act, supra n. 2 at s. 127 (2.1).

76. (1985) 37 Alta. L.R. (2d) 70 (Q.B.).

77. This case went through two stages. In the first stage, the plaintiff had challenged the transaction on the basis that it constituted a gift and not a sale and that the land was being held in trust on its behalf. This issue worked its way up to the Court of Appeal where it was held that there was indeed a contract of sale with consideration flowing from both sides of the transaction. The court stated that, in addition to the $\$ 1.00$, the purchaser had made itself "liable for the very onerous promise of constructing the building". The court, however, did not rule on the question of whether the consideration met the requirements of s. 127, which was the subject matter of the second stage. See Yellowhead Regional Library Board v. Spruce Grove (1983) 24 Alta. L.R. (2d) 163 (C.A.).

78. It was so held in Tietzen v. City of Edmonton, supra $\mathrm{n}$. 13. In Tietzen the chambers judge held that municipal concessions relative to terms of payment were authorized by s. 127 to the same extent as relative to price. 
the council had taken the precaution of requiring the construction of the proposed development to be effected.

\section{THE CURRENT STATUS OF BONUSING}

What about other forms of municipal inducements to secure the establishment, continuation or expansion of a private business enterprise such as, for instance, an outright grant of municipal funds? Are they now lawful without more in light of repeal of s. 443? In the writer's view these too remain illegal.

In a nutshell, the proposition is that, even where there exists an express prohibition against bonusing, the threshold question to be answered in determining the vires of a municipal expenditure of funds or other resource is, can the municipal action taken be supported under some express power in the municipal legislation or, if not pursuant to an express power, is the action taken one that is by necessary implication inherent in an express power that has been conferred? If the answer is in the negative, that is the end of the matter. The municipal action in question is illegal because it has no statutory foundation. Repeal of s. 443 does not somehow magically fill in the void in the legislation. The existence or non-existence of a provision like s. 443 can, thus, be seen as of no particular consequence in determining the vires of a grant.

If, on the other hand, the answer to the threshold question is in the affirmative because the power exercised is apparently pursuant to an express or necessarily implicit grant of authority, the next question to be addressed is, are the circumstances surrounding the exercise of the power such as to demonstrate that the power was exercised in bad faith? Bad faith will be found where there is no evidence of any real benefit accruing to the municipal body politic of the kind that normally flows from the exercise of the statutory power in question. If there is some such benefit and it is not specious so as to be a sham that, again, is the end of the matter since the courts will not second guess the sufficiency of the benefit.

Conversely, if no such benefit exists that too is the end of the matter. In that event the action is illegal because the statutory authority has been used for an improper purpose and can thereby be seen to be exercised in bad faith. The existence or non-existence of an express bonusing prohibition is not material to the inquiry.

Admittedly, where there exists an express prohibition like the former s. 443 , the inquiry of the court can be short-circuited. Instead of proceeding through the steps outlined above, where there is an express prohibition, a court could simply ask itself, is the only motivation for and the only benefit accruing to the municipality and its citizens from the action taken, the securing of the business enterprise in question and the benefits that naturally arise therefrom? If that is the case, the action is covered by the express prohibition. If there is some other legitimate, statutorily based municipal objective and if the benefits accruing to the municipality go beyond those that naturally arise from the establishment of the business, the action is not encompassed by the prohibition.

In the final analysis, repeal of the express prohibition merely changes the nature of the inquiry, but the result will be the same. 


\section{THE OMNIBUS CLAUSE AS AUTHORITY FOR BONUSING}

One final matter needs to be addressed. Albeit there is no express authority in the Municipal Government Act empowering a council to give grants and other aid for the sole purpose of enticing a private business enterprise to establish itself in the council's territorial jurisdiction, it might be argued that the repeal of $s .443$ opens the door to the proposition that such power is now to be found in the peace, order and good government clause of the Act. ${ }^{79}$

The scope and operation of the omnibus clause and the extent of recognition it has been accorded by the courts is a story unto itself, what with municipal councils utilizing it to pass by-laws in respect of such diverse matters as establishing daylight saving time, prohibiting the sale of liquor to insane persons, establishing a municipal gazette, prohibiting distribution of handbills, creating non-smoking areas in public places, regulating display of adult-oriented magazines in stores and declaring a municipality a nuclear-free zone.$^{80}$ However, for purposes of the topic at hand, the discussion of the clause can be focused around the basic rules of statutory construction in respect of special versus general enabling provisions in municipal legislation and seeing where the rules take one.

The starting point is what one commentator has called "Dillon's rule", which has previously been explored. To restate the rule, a municipal council may only exercise the powers expressly conferred, those fairly implied by the express power and those powers that are necessarily incidental, and not merely desireable, to the effective governance of the municipality. This dictum has fostered the proposition that the omnibus clause cannot be used to clothe a council with a power, the exercise of which would operate to either derrogate from or enlarge some special or express grant of power contained elsewhere in the municipal enabling legislation. Similarly, it cannot be used to derrogate from or enlarge some express prohibition contained in the legislation. These principles of statutory construction, of course, are embodied in the well-known Latin maxims generalila specialibus non derogant and expressio unius est exclusio alterius.

To illustrate, in Ward v. City of Edmonton ${ }^{82}$ it will be recalled that the City council had made grants to certain charitable and similar organizations. These grants were challenged as being in contravention of the prohibition against bonusing found in the enabling legislation and, in any event, on the basis that there was no provision in the enabling legislation

79. Municipal Government Act, supra n. 2 s. 112, which provides:

112. A council may pass by-laws that are considered expedient and are not contrary to this or any other Act,

(a) for the peace, order and good government of the municipality,

(b) for promoting the health, safety, morality and welfare thereof, and

(c) for governing the proceedings of the council, the conduct of its members and the calling of meetings.

80. See generally, Rogers, supra n. 16 at 357-361.

81. Makuch, Canadian Municipal and Planning Law (1983) at 115 . The rule comes from Dillon, 2 Municipal Corporations (5th ed.) at 585 and 586.

82. Supra n. 23. 
giving council power to make the grants. In response to the latter argument, the City invoked the omnibus clause. The court held that the above described principles of statutory construction of municipal legislation were correct and applicable. Yes, there was an express prohibition against bonusing in the legislation but that express prohibition did not apply to grants, the court finding bonuses to be different in kind from grants. Moreover, there were no provisions in the enabling legislation dealing with grants to private organizations. This motivated the court to find that the omnibus clause operated to empower the Council to make the grants in question. The court, in effect, found that there was no special or express provision in the enabling legislation dealing with grants, the bonusing provision having been found not to apply to grants. Therefore, it was open to the court to employ the omnibus clause. In so doing, the court was not adding to or derrogating from any express enabling or prohibiting section.

Another Alberta case ${ }^{83}$ demonstrates the result where an attempt is made to use the omnibus clause to support a by-law where the subject matter of the by-law is expressly dealt with in another provision of the municipal legislation. In that case, the City of Edmonton passed a by-law making an owner liable to prosecution for the parking of his motor vehicle on private property where the property was posted with a "no parking" sign. The municipal legislation had a specific and express provision empowering a council to pass a by-law making it an offence for the driver of the vehicle to park it on posted private property. In holding the by-law ultra vires the court stated that the by-law in question could not be passed under the omnibus clause because that clause was not to be used to support a by-law which dealt with a subject matter expressly provided for in a specific provision, that went beyond that which was authorized in the specific provision. In other words, the omnibus clause could not be used to enlarge upon the limited authority conferred in the specific provision..$^{84}$

Applying the foregoing principles to the matter of grants and other like aid to entice the establishment of private businesses in a municipality, in the writer's opinion, the omnibus clause cannot be used to support such actions. This is so because there are numerous sections in the Municipal Government Act conferring express authority on councils to give grants, but in limited circumstances. ${ }^{85}$ Hence, to construe the omnibus section as enabling a municipal council to give such grants to entice private developments would be to utilize the general section to derrogate from limitations contained in express and specific provisions dealing with grants. Such construction of the omnibus clause would be contrary to the weight of the authorities. ${ }^{86}$

83. Reg. v. Anderson (1958) 24 W.W.R. 53 (Alta. D.C.).

84. See also Rogers, supra n. 16 at 357-360 and Makuch, supran. 81 at 115-118, together with the cases cited therein.

85. Supra n. 58.

86. There are some contrary but wrongly decided cases. (See Rogers, supra n. 16). 


\section{CONCLUSION}

The rule that prohibits municipal councils giving tax exemptions, grants and like aid to private business enterprises to entice continuation, expansion or establishment of such enterprises in the community likely remains alive and well in Alberta despite the repeal of s. 443 of the Municipal Government Act. It seems that the more things change, the more they remain the same. 